\title{
Et gjesp fra fortiden
}

Gjesping er smittsomt, men sjelden uttrykk for sykdom. For noen år siden hadde jeg en 49 år gammel pasient med venstresidig hemiplegi som jeg fikk til å gjespe (video). Jeg lar John Abercrombie (1780-1844) beskrive ham: «I had some time ago under my care, a man affected with hemiplegia of the left side, the palsy complete, without the least attempt at motion, except...every time he yawned the paralytic arm raised up...» (1).

Dette besynderlige fenomenet er i moderne litteratur omtalt kun et fåtalls ganger (2). Det har fătt benevnelsen parakinesia brachialis oscitans (parakinesia $=$ ufrivillig abnorm bevegelse, brachialis $=$ arm, oscitans = gjespe). Tap av voluntær bevegelse $\mathrm{i}$ armen skyldes utvilsomt en skade i pyramidebanen (tractus corticospinalis). Mekanismen bak parakinesia brachialis oscitans er ukjent, men muligens er fenomenet et resultat av frigjort aktivitet $i$ et fylogenetisk gammelt og mer primitivt ekstrapyramidalt system (2). Hos firbeinte dyr er det nemlig en klar kobling mellom åndedrett og bevegelse i ekstremitetene. Hest synkroniserer f.eks. steg og respirasjon i en 1 til 1 ratio (steg/åndedrett) under galopp. Hos tobeinte er denne synkroniseringen gått tapt. Dersom du ikke allerede har tatt hånden til munnen for et forløsende gap, kan du se videoen en gang til.

Pasientens pårørende har gitt samtykke til at artikkelen blir publisert.

\section{Karl B. Alstadhaug}

alstadhaug@operamail.com

Nevrologisk avdeling

Hode- og bevegelsesklinikken

Nordlandssykehuset Bode

Karl B. Alstadhaug (f. 1972) er overlege og spesialist i nevrologi.

Forfatter har fylt ut ICMJE-skjemaet og oppgir ingen interessekonflikter.
Litteratur

1. Bell C. The nervous system of the human body: as explained in a series of papers read before the Royal Society of London. London: Henry Renshaw, 1844: 411. http://books.google.no/ books? id=EBk1AQAAMAAJ\& $h l=$ no\&source $=g b s$ book_other_versions (27.3.2013)

2. Walusinski O, Neau JP, Bogousslavsky J. Hand up! Yawn and raise your arm. Int J Stroke 2010; 5 : $21-7$.

Mottatt 29.1. 2013, første revisjon innsendt 27.3. 2013, godkjent 26.4. 2013. Medisinsk redaktør Merete Kile Holtermann. 